\title{
Atomistic versus holistic semiotics
}

\author{
Mihhail Lotman \\ Department of Semiotics, University of Tartu \\ Tiigi St. 78-310, Tartu 50410, Estonia \\ e-mail: mihhail@ehi.ee
}

\begin{abstract}
The paper is devoted on the foundations of semiotics. It examines the specific features of Peircean and Saussurean traditions and demonstrates that the basis of all the differences is the different conception of the nature of sign: Peirce proceeds from the substitutive concept, Saussure from the bilateral one. The substitutive construction is atomistic by its nature: it is based on a (single) sign which replaces a (single) object, while bilateral is holistic: it is based on the sign system which is divided into (single) signs. The differences of semiosis in atomistic and holistic approach will be pointed out.
\end{abstract}

Our conference consists of two main sections, one of them is more focussed on the semiotical theory, the other concentrates on Russian culture and literature. Therefore I have to keep in mind both the problematics, yet it will inevitably cause difficulties, since I have to tack between the so-to-say Scylla of banality and Charybdis of excessive specificity. The compromise will probably not satisfy anybody. My solution is that I try to illustrate some of the statements in the sphere of general semiotics with examples from, above all, Russian poetical culture, and, thus, I must apologize to semioticians for the retelling quite known statements and to theorists of Russian literature for the triviality of examples.

$* * *$

When we observe the development of semiotic studies during the last 50 years, then, on the one hand, we can not disregard an enormous amount of practical researches, processing of a great scope of materials, but, on the other hand, an obvious stagnation in the sphere of semiotic theory. Moreover, when we compare the present situation 
with that of the beginning of the 20th century, the theory of semiotics seems to face now even bigger obstacles. Peirce's outstanding contribution to the clarification of the nature of semiosis and systematization the types of signs and Saussure's prophetic intuitions in semiology did not yet meet with an actual material, which not only resists given approaches, but to a certain extent even contradicts them. The situation is even more complicated by the fact that schools which pursue their activities under the general heading of semiotics differ from each other not in details, but in their basics and it is almost impossible to find a compromise or common part between them.

Above all, we should distinguish the Peircean and Saussurean traditions. At first sight it seems that the contributions of the abovementioned scholars are not comparable to one another at all. Against Peirce's detailed, accurate and, last, but not least, extremely capacious treatment of signs we could counterpoise a few dozen of pages of Saussure's quite vague lines of thoughts, which, all the more, sometimes contradict one another. Wouldn't it be more expedient, then, to forget Saussure at all, as some of the Peirce's followers earnestly suggest? E.g., when I tried to discuss with Roberta Kevelson the problem of the arbitrarity of sign in Peircean and Saussurean works, then, regrettably, the discussion did not work out, since all my attempts ended with Roberta Kevelson's verdict: if Saussure had thought it through more carefully, then he wouldn't have said what he said, but would have understood that things are like Peirce has said. Thomas Sebeok was even more resolved in this matter. Even in his public lecture he expressed the differences between Saussure and Peirce, roughly, in the following way: if Saussure had drunk less, then he wouldn't have written all these obscure things and would have come to the ideas which can be found in Peirce's works. We can find variations in this theme in several other scholars, of which Roman Jakobson should be especially mentioned, because he was very close to the Saussurean tradition in 1930 s, but later resolutely crossed over to the Peirce's paradigm.

As for my opinion, then I am absolutely convinced, that even if Saussure (who, by the way, was not a drunkard at all) had completely given up alcohol, he still wouldn't have reached the Peirce's concepts and even if Peirce had drunk a couple of bottles of wine everyday and used other mental stimulations as well, he still wouldn't have reached those, in my opinion, extremely important ideas which Saussure tried to express. 
Peirce's approach to signs could be called atomistic. In the centre of attention there is a (single) sign. From the standpoint of the Peircean semiotics, sign is elementary and, semiotically, the smallest element. Since the whole construction of semiotics depends on what sign is, he payed so much attention to the exact description of sign. There are 88 definitions of sign in Peirce's works which, in essence, are all variations in the same theme. The most famous of them is the following: "A sign, or representamen, is something which stands to somebody for something in some respect or capacity" $(2,228)$.

Although the definition of sign is in both Peirce's and Morris' studies purely relativistic (the sign is formed by the system of relations), nevertheless, sign is semiotically an elementary object, it does not consist of any smaller components. I would like to emphasize that I mean namely semiotical, not, e.g., physical elementarity. Since sign can be any object (something), then it could have a quite complicated structure, but, semiotically, it is still elementary; it does not consist of smaller semiotically relevant components. Single signs constitute complex signs, expressions which in sum form a language. When, e.g., Noam Chomsky defined language as a complex of grammatically correct sentences (Chomsky 1957), then, without referring to Peirce, he proceeded from the same point of view. An utterance, as well as a language as a whole are in comparison with a single sign secondary and a lot more complicated objects. E.g., in generative grammar and studies close to this approach language is defined in the following way: $L=\{A, G\}$, where $A$ is alphabet or lexicon $A=\left\{a_{1}, a_{2}\right.$, $\left.\ldots, a_{n}\right\}$ and $G$ is grammar or the set of rules $G=\left\{r_{1}, r_{2}, \ldots, r_{m}\right\}$. Hence, a lexicon, which we could conceive, e.g., in the case of a natural language as a scope of linguistic signs, is closed and primary, while a language as a whole is open and secondary. Therefore, we should not wonder that for Peirce, language is in comparison with sign far less an important phenomenon: the correct description of signs guarantees the correct description of language.

Such treatment seems to be simple and logical. When we now turn to Saussure, then we notice a completely different and strange logic. For Saussure, an isolated sign does not exist at all. From his viewpoint the whole scheme of Peirce's semiotics is incorrect, a sign is formed not by its relation to an object or a user of sign, but with other signs which belong to the same sign system. Here we are dealing with an obvious paradox. The precondition of signs are other signs, 
moreover, a sign system, a language, to where it belongs. Peirce's single sign is something clear and accurately defined, while language, being formed of signs, is in a way indefinite formation, at least a lot more complicated than sign. For Saussure, it is vice versa: language is a primary reality, with the clear structure which is divided into single signs with not so clear or elementary nature. Up to now, this fundamental fact, that for Peirce and Saussure, one and the same word 'sign' designates completely different objects, has not been explicitly pointed out. For Peirce, sign is a concrete object, it is a substitute which replaces another concrete object (I would rather not get into an argument now, whether such sign as 'abstract' is concrete or not, it is enough to point out, that, in my opinion, we are dealing in such cases as well with concrete objects and signs), for Saussure, sign is an abstract object which is realized in a concrete substance, and, what is most interesting, this realization in a way compromises its semiotic nature: the sign realized in speech is not, literally, a sign at all.

As it is known, Saussure divides the sphere of language (langage) into a language itself (langue) and speech (parole). In such distinction two circumstances seem to be the most important. First, language is an abstract system which is primary with regard to speech. Language is represented in speech, whereby in the latter only how and to what extent it realizes the structure of language is linguistically relevant. ${ }^{1}$ Secondly, only language (and not speech) constitutes a sign system. The latter seems to be especially paradoxical: the speech signals (not only the single sounds, but full sentences as well) which are said and sensed are not signs by itself, they only represent signs of language. This can be expressed with the scheme on Fig. 1.

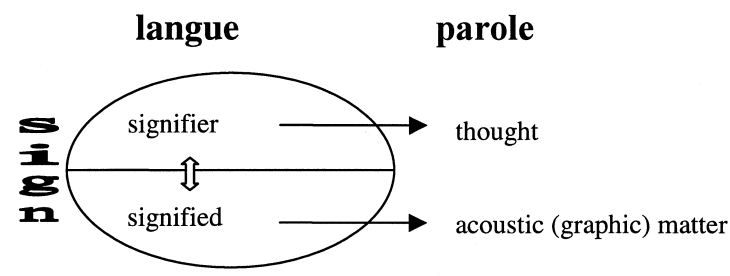

Figure 1. Saussure's concept of language and speech (reconstruction).

1 Saussure emphasizes it categorically: "As for all the other elements of speech activity, then linguistics could completely do without them" (Saussure 1982, 31). 
For Saussure, there is no direct connection between the conceptual sphere and the voiced speech, between thought and acoustic matter, they are only related to each other indirectly, due to the fact that they both realize signs of language. The central part in this scheme belongs to the relationship which connects the signifier and the signified of a sign (later Louis Hjelmslev calls this relationship the sign function). Although usually there is no treatment of semiosis in the Saussurean tradition and this term is not in use, we could still say that namely the sign function is the basis for the formation of sign (i.e. semiosis). Hence, differently from that of Peirce, Saussure's sign is, first, abstract and, secondly, complex. The central problem of Saussure's semiotics is the relationship between the signifier and signified. To characterize the relationship between the signifier and signified, Saussure offers a scheme (Fig. 2).
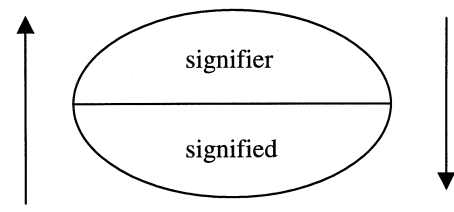

Figure 2. The relationship between the signifier and signified, according to Saussure (1982: 158).

Saussure emphasizes two things: first, the symmetry of signifier and signified and that one can not exist without another, and secondly, the arbitrarity of their relationship. It seems that here we are dealing with an obvious contradiction. On the one hand, the sign of language is something certain, being determined by the system of language, on the other hand, the relationship between the components of sign is fully optional, arbitrary. To solve this dilemma, Saussure distinguishes meaning and value (valuer). Arbitrarity characterizes the meaning of sign, the absolute determination characterizes the value of it. Meaning arises from the relationship between the signifier and signified, value characterizes the position of an element in a system, i.e. value is the complex of all the internal connections of the given element in the given sign system. Saussure has illustrated this statement by a scheme (Fig. 3). 


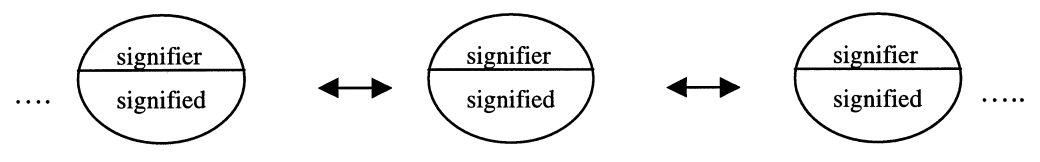

Figure 3. Value as the position of an element in a system (Saussure 1982: 159).

At the same time, Saussure emphasizes that the connections, which connect different signs, differ, in principle, from those, which create the correspondence between the signifier and signified: the connections, which connect signs, have determinative nature. The most problematical is here the linear alignment of signs. Probably we should not pay too much attention to it, since, obviously, we are dealing with the inertia of the linearity of speech.

Hence, differently from Peirce, for Saussure the proceeding-point is language and its structure which, to his mind, are fully clear and fixed, while the single elements of language, incl. the question of the sign of language, are problematical. While we called the Peircean approach to semiotics atomistic, then the Saussurean approach should be called holistic. The subsequent studies in the sphere of the semiotics of language showed that the Saussurean approach, regardless of its above-discussed paradoxicality, appears to be far more powerful and productive. One of the examples is the problem of meaning of grammatical categories. Especially remarkable is that the contemporary formulation was given to this problem by an outstanding American linguist Edward Sapir, who, as it is known, was not the direct follower of Saussure. Nevertheless, his conception of grammatical categories has been developed in the Saussurean, i.e. in the holistic spirit (Sapir 1921; also Whorf 1945). The complex of grammatical categories is one of the most important parameters of the description of language. These are individual for every language and what functions as a grammatical category in one language, does not have to do so in another language. E.g., the Estonian language in comparison with Indo-European languages "lacks" the categories of grammatical gender or future tense. This "lacking" can not be explained in Peircean terms through the relationship between the object and interpreter of sign, it is a parameter which characterizes the Estonian language as a whole. This "lacking" can be discovered only if we compare the Estonian language as a whole with some other language. 
At the same time, Sapir shows the semiotic nature of grammatical categories. These are not only the schemes of conjugation or declination, but the conceptual network with which language creates its own world-view. It is a very important fact: at least part of the signs of language is not given in advance, but at the same time they are not an open set, as, e.g., words in a lexicon; grammatical categories are the signs which clearly represent the Saussurean valeur.

Proceeding from his idea of sign, Peirce creates a rather complicated typology of signs, of which the most important part constitutes what Peirce himself call the second trichotomy of sign: the iconic, indexical and symbolic signs. The basis of this classification is the nature of connections between signs and objects signified by them. When we approach this problem in the Saussurean spirit, then we have to mention that all what is discussed by Peirce, characterizes not language, but speech; the signs of language, in Saussure's opinion, are of the same type. As it was pointed out by Jerzy Pelc in a paper exclusively devoted to this problem, when we speak of iconic signs, it would be more correct to speak of the iconical usage of a sign, i.e. iconicity evolves in speech (Pelc 1986). Proceeding from the analysis of language by Charles Bally and especially Emile Benveniste, we could most certainly assert that the same applies to the indexical signs as well: there is no indexicality in language, it evolves in speech, in every certain speech act (Bally 1965, Benveniste 1966). But it would be inconsiderate to conclude, as does, e.g., Roman Jakobson, that only symbolic signs can be found in language, since symbolic signs can not exist without icons and indexes. What I intend to say, is that all the Peircean types of signs characterize only speech, as for the signs of language, then they are based on a principally different logic, which is grounded on the values of sign, not on its connections with objects.

In comparison with natural language, the problem of sign is a lot more acute in these semiotic systems that in Tartu-Moscow semiotics are called secondary modelling systems. While in the case of language the intuitive concept of sign is somehow related to word, then in these systems it is often not clear even in intuitive level, what sign is.

Let us take, for example, poetry. On the one hand, a poetical text consists of words and sentences, e.g., of elements which have a status of sign in natural language as well. On the other hand, it is obvious, that, first, the problems of poetical signs are not solved with it, there 
are several other elements which are connected with the semantics of text (verse metre, rhythm, rhyme, alliteration, etc), secondly, elements, which can be found also in language, in poetry as compared with prose text mean something else and do it in a different way. Michael Riffaterre even says:

The language of poetry differs from common linguistic usage - this much the most unsophisticated reader senses instinctively. [...] To put it simply, a poem says one thing and means another. (Riffaterre 1978: 1)

Although this formulation seems simplified and overbidding: poetical text can be very straightforward in its expression, nevertheless, it is not necessarily always so and semiosis of verse has its own important specific features, Riffaterre refers to an actual problem, the more correct formulation of which is as follows: why can the same words and sentences mean something else and more in poetry in comparison with prose? Since everything that creates a semantic effect should have a status of sign, then a question arises: what is sign in verse?

Atomistic point of view offers here two alternatives, of which one could be called reductionistic, the other pansemantic. The reductionistic approach reduces all the elements of verse to natural language and all meanings to the meaning of language. According to this, all the signs in verse are signs of language. The fact, that in verse text we find more images and words used in a strange way, can be explained with the means of stylistics and rhetorics, i.e. we are not dealing with specific signs, but with the specific usage of signs. As for such elements which can not be found in language, as, e.g., the already mentioned verse metre, rhyme, etc, then, first, we are not dealing here with independent elements at all, verse metre is an abstraction which can be derived from the configuration of words and other linguistic elements, secondly, they are asemantic; verse metre, stanzaic form, rhyme, alliteration, etc, do not mean anything in itself. Only the words that constitute lines, stanzas, rhymes, etc, have meaning. Thus, e.g., the researcher of Russian poetical language Viktor Grigorjev distinguishes a semantical sphere in poetical text, which corresponds to linguistical semantics, and "wrapping-material", the usage of which has no semantical meaning, they just frame and keep together the semantically relevant material (Григорьев 1983).

The pansemantic approach, on the contrary, argues that all the elements of verse text have meaning, from words to the last comma. Cf., e.g., Claude Lévi-Strauss' and Roman Jakobson's analysis of the famous Baudelaire's sonnet “Cats" (Jakobson, Lévi-Strauss 1962). 
The holistic point of view, on the other hand, proceeds from the idea that elements of poetical text, their nomenclature and semantics are not given a priori nor in natural language, neither anywhere else. They are function of the given concrete poetical language. Consequently, we can not declare that all elements have always an actual meaning, or that there are elements of verse text that have no meaning under any circumstances (wrapping-material), but that all the elements are related to meaning only potentially (and the amount of elements is not determined a priori).

Further some other examples will be examined.

One of them is the problem of film language. On the one hand, it is absolutely clear that in case of film we are dealing with a sovereign semiotic system, which has its own regularities, on the other hand, the problem of film sign is not an easy one. What is film sign? E.g., Christian Metz treats this problem in a simple way: all what we see on the screen is sign (Metz, 1974). When we see a dog, then the dog is sign, when we see the tail of a dog, then the tail of a dog is sign, when we see the tail hair of a dog, then the tail hair of a dog is sign, etc. Since the object of filming can be anything, then the amount of film signs is open and potentially infinite. This means, apropos, that film does not have its own specific language, it depends only on the type of mimesis. Film sign originates only as a result of reflecting the reality. All this resembles a lot the reductionistic approach to the problem of poetical sign, but it is even more mechanical, since here is no semiotical mediator between the world and text. We can come across such approach as well in other studies devoted to the sphere of visual semiotics. Although the title of the book by Christian Metz is Film Language: A Semiotics of the Cinema, he does not really describe film language, but only single film signs.

However, such approach seems to be rather simplified: e.g., what means 'is on the screen?' Or 'in the frame?' What is frame itself? It is obvious, that here we are not dealing with the same type of element as, e.g., the tail of a dog. Figuratively speaking, nobody goes to the movies to watch frames, but namely the tail of a dog. But the tail of a dog in a movie differs from a real tail of a dog by being placed in a frame, it has become an element of a frame. Hence, in a movie we are dealing not with a tail, but with a tail-in-frame. But a frame is one of the elements of film language, its structure characterizes the concrete film language. 
Not only what is in the frame is important, but also, as well as in the case of natural language, what is outside of it. We do not see an element, but we sense its absence. It is so-to-say the Saussurean zerosign. Consequently, we can not speak of one universal film language, but of different film languages which have complicated relationships with one another. One and the same tail in different frames can mean completely different thing, i.e. they can be different signs.

The advantages of the Saussurean approach come forth especially clearly, when we analyse the language of music. In the Peircean spirit we could mention here the onomatopoetical phenomena in music (cf, e.g., the sounds of a cuckoo or some other animal in Camille SaintSaëns" "Carnival of the animals", etc.), these are iconic signs in music, while in the so-called concrete music, where, e.g., a horn refers to hunting, the sound of a motor-cycle to a motor-cycle, we could speak of musical indexes. However, all the rest involves major problems for the semiotic analysis: perhaps we are not dealing here with signs at all? But what is music itself? The atomistic approach could proceed, e.g., from the objective qualities of sounds and try to build up from the musical phrases. But in the Saussurean holistic spirit primary is the language of music, e.g., Arnold Schönberg's dodecaphony, while the physical qualities of sounds are of secondary importance. What is an element in the given language of music, depends on language a lot more than on the physical parameters of sound. In that spirit the problem of the musical sign should be solved as well. To Boris Gasparov's mind in the musical language of Modern Europe not single sounds or notes function as signs, but motifs. But what should be considered motifs, depends on the concrete language of music.

Up to now we proceeded only from Saussure's view-point. However, the Saussurean approach has a series of qualities, which make it inconvenient for the semiotics of culture. Here I have in mind, above all, his superior attitude towards speech and all the empirically given phenomena. The Saussurean approach is platonistic, he is first of all interested in pure ideas and language is one of these ideas.

Saussure's followers - here I mean above all the Prague Linguistic Circle, but also Émile Benveniste, Roman Jakobson and Claude Lévi-Strauss, as well as the representatives of Tartu-Moscow semiotic school - so-to-say rehabilitate speech. First, it turned out that speech has also a semiotic nature, and - what is especially important for us, this nature is not an automatic consequence of realization of the system of language. Émile Benveniste emphasizes that speech has its own semiotic qualities, which are not derived from 
language (Benveniste 1966). Secondly, speech can also be a closed and stable system. Such system was to be called text. Levi-Strauss analysed the ritual and mythological text in the way Nikolai Trubetzkoy analyses the phonological system of language. In the case of artistic text, Tartu-Moscow semiotic school has achieved analogical results. Hence, text is an immanent system, the elements of text form a structure and every element of text has its own certain value.

I would now like to return to the semiotics of verse and illustrate this statement with some examples. The length of verse is a relative parameter. An iambic tetrameter, being surrounded with dimeters, is opposed to them as long, if it is surrounded with hexameters, then as short. The length or shortness of a verse is an important parameter. In the case we are dealing with stanzas which consist of verse lines with different length, then, e.g., in Russian poetry, clearly more preferred are such stanzas which, on the one hand, begin with a longer, and, on the other hand, end with a shorter verse. Especially obvious are the preferences of a shorter verse in the last position. Usually it is interpreted as an iconic sign of completion and incompletion. A shorter verse so-to-say puts an end to a stanza. In the case we are dealing with an alternation of masculine and feminine endings, then the stanzas which begin with a feminine ending and end with a masculine ending are preferred. Such is the general tendency. But in concrete texts it enters into complicated relationship with other codes, which are realized in this text, above all, with the verbal code. As a result, a shorter verse may acquire completely another, even the opposite meaning. Hence, Nekrassov's poem devoted to Tarass Shevtshenko's death has the following ending:

$\begin{array}{lll}\text { Но, сократить не желая страдания, } & \text { D4 } & \text { A' } \\ \text { Поберегло его в годы изгнания } & \text { D4 } & \text { A' }^{\prime} \\ \text { Русских людей провиденье игривое. } & \text { D4 } & \text { B' } \\ \text { Кончилось время его несчастливое, } & \text { D4 } & \text { B' } \\ \text { Все, что он с юности ранней не видывал, } & \text { D4 } & \text { C' } \\ \text { Милое сердцу, ему улыбнулося, } & \text { D4 } & \text { D' } \\ \text { Тут ему бог позавидовал: } & \text { D3 } & \text { C' } \\ \text { Жизнь оборвалася. } & \text { D2 } & \text { D' }^{\prime 2}\end{array}$

${ }^{2}$ D2, D3, D4 - mean resp. dactylic dimeter, trimeter and tetrameter; A', B', etc. - mean different dactylic rhymes. 
It is a long poem, written in the dactylic tetrameter which is contrasted by two shorter final verses. The whole poem is devoted to Shevtshenko's hard fate and tragic life, only at the beginning of the final stanza there is a brighter moment which is overbalanced right away. Two final verses have the following meaning: "at this point, god envied him: / the life was interrupted". The metrical change harmonizes with the ellipticity of syntax. But for us extremely important is the last verse. Shevtshenko's life is interrupted before its so-to-say logical end and this interruption is iconically expressed by the last, twice as short a verse: "life was interrupted" seems to be an interrupted verse. Yet this poem is not that simple and the tension between the completion and incompletion is far from being solved with that: metrically unfinished verse ends the poem and its metrical incompletion is in conflict not only with the compositional, but as well with the rhyme completion. The unfinished verse has not only a verse ending, but as well the rhyme of this ending, so that we are dealing with the so-tosay completed incompletion. We find a different example from the Alexei Apuhtin's poem - a self-murderer's farewell letter. It ends in the following way:

Пусть мой последний стих, как я, бобыль ненужный,

Останется без рифмы...

Let my last verse like me, an needless bachelor remain without a rhyme...

Here indeed the final verse is not only shorter, but differently from all the previous verses, it is also without a rhyme. It is interesting, how the meaning of the poem, its images and verse structure amplify each other. The Russian word 'бобыль' has several meanings, in the context of this poem it means, above all, a person who is not needed by anyone. One of its meanings is also 'an unmarried man'. But 'unmarried' in the Russian poetical tradition is also an unrhymed verse (although it is never designated with the word 'бобыль'). The motif of an unneeded person and the non-ended end is expressed here in three different levels.

Hence, when we are dealing with some elements of the poetical text, then we can not quite successfully analyse their meaning proceeding from atomistic ideas. The semantics of a single sign depends on the meaning of the entire text. As even these simple examples suggest, the limits of the whole text will not be sufficient, we have to treat them in wider context, considering also the entire tradition and 
culture. But how would it look like in practice? How can we analyse a tradition, before we have analysed all the single authors in it and how can we treat the entire creation of an author before we have analysed all his works? It seems, that we are dealing with such problems which appear to be more complicated in the theoretical level than in the actual analysis. As it is usual in the case of humanities, we are dealing here with one hermeneutical cycle, where in analysis of single phenomena the whole is being kept in mind, and vice versa, in analysis of culture and tradition, its complexity is being considered. I will give only one example: the Russian iambic tetrameter. In the 18th century it became an official odic verse metre. In Pushkin's time both its rhythmical and semantical structure changed. After Pushkin his successors canonized the rhythm and sound of Pushkin's verse. During the last half of the 19th century its meaning became official and was associated with the golden era of Russian poetry. In the beginning of the 20th century the new sounds and rhythms evolved, whereby some of them referred to the 18th century (Mikhail Gasparov calls them archaistic - Гаспаров 1974), and some of them to the Pushkin's tradition. Andrei Belyi, an outstanding poet and scholar, opposes in his poems different rhythmical types of iambic tetrameter and gives this opposition also the meaning. It was for the first time in Russian poetry, when the different rhythmical types of one and the same verse metre were brought into consciousness and semantisized (Tapaновский 1966). In the contemporary Russian iambus there can be found very different rhythmical traditions, incl. Lev Rubinshtein's, again described by Mikhail Gasparov: Rubinshtein writes as if he were the first iambic writer in Russian poetry, whereby his iambs sound completely uniambic and unpoetical (Гаспаров 2000: 313314). In the Saussurean spirit we could here speak of the zero-sign. An iambic tetrameter designates here non-poetry. To carry out such an analysis, we must consider the tradition of the whole Russian poetical development which, thanks to Kirill Taranovsky, Mihhail Gasparov and others, for the time being, it has been accomplished to great extent.

$$
* * *
$$

Conclusion. In the contemporary semiotics we can see a certain disproportion between the semiotical theory and practical results. Using the offered terms, the semiotical theory proceeds above all from the atomistic paradigm, but the most important and interesting results 
from the holistic one. Consequently, the practical task, in my opinion, is to develop the holistic semiotical theory. According to my convictions, the basic concept of the holistic semiotics has to be translation. First, the typology of texts and languages which is analogical to the Peirce's typology of single signs has to be created. Secondly, the theory of mutual influences and correspondences between texts and languages has to be worked out.

\section{References}

Bally, Charles 1965. Linguistique générale et linguistique francaise. 4th ed. Bern: Francke.

Benveniste, Émile 1966. Problémes de linguistique générale. Paris: Gallimard. Chomsky, Noam 1957. Syntactic Structures. The Hague: Mouton.

Jakobson, Roman; Lévi-Strauss, Claude 1962. 'Les Chats' de Charles Baudelaire. L'Homme 2: 5-21.

Metz, Christian 1974. Film Language: A Semiotics of the Cinema. Trans. Michael Taylor. New York: Oxford University Press.

Pelc, Jerzy 1986. Iconicity: Iconic signs or iconic uses of signs? In: Bouissac, Paul; Posner, Roland; Herzfeld, M. (eds.), Iconicity: Essays on the Nature of Culture. Festschrift for Thomas A. Sebeok on his 65th birthday. (Problems in Semiotics 4.) Tübingen: Strauffenburg-Verlag, 7-16.

Peirce, Charles Sanders 1931-1958. Collected Papers of Charles Sanders Peirce, vols. 1-8. Cambidge: Harvard University Press.

Riffaterre, Michael 1978. Semiotics of Poetry, Bloomington: Indiana university press

Sapir, Edward 1921. Language: An Introduction to the Study of Speech. New York: Harcourt, Brace and Co.

Saussure, Ferdinand de 1982 [1916]. Cours de linguistique générale. Édition critique préparé par Tullio de Mauro. Paris: Payot.

Whorf, Benjamin Lee 1945. Grammatical categories. Language 21: 1-11.

Гаспаров, М. Л. 1974. Современный русский стих. Москва: Наука.

- 2000. Очерк истории русского стиха. Метрика. Ритмика. Рифма. Стро$\phi и к а$. Издание второе (дополненное). Москва: Фортуна лимитед.

Григорьев, В. П. 1983. Грамматика идиостиля: В. Хлебников. Москва: Наука.

Тарановский, К. Ф. 1966. Четырехстопный ямб Андрея Белого. International Journal of Slavic Linguistics and Poetics 10. 


\section{Атомистическая и холистическая семиотика}

Статья посвящена основаниям семиотики. Показывается, что несмотря на ряд потыток построения синтетической теории, расхождения между пирсовской и соссюровской традициями оказываются непреодолимыми. В основе различий лежит принципиально иная концепция природы знака: для Пирса знак - объект, заменяющий другой объект, становящимся значением знака (такую концепцию знака можно назвать субститутивной), для Соссюра - значение не существует вне знака; означаемое и означающее не могут существовать друг без друга (такую концепцию можно назвать билатеральной). Субститутивная концепция является атомистической: в основе ее лежит понятие (отдельного) эмпирически данного знака, замешаюшего (отдельный) объект, в то время как билатеральная концепция подразумевает холизм: в основе ее лежит понятие абстрактной системы знаков, разлагаемой на отдельные знаки. В атомистической и холистической семиотиках принципиально иначе должно рассматриваться и понятие семиозиса: в атомистической семиотике в основе семиозиса лежит процесс идентификации, в холистической трансляции (перевода в семиотическом смысле).

\section{Atomistlik ja holistlik semiootika}

Artikkel käsitleb semiootika alusküsimusi. Vaatamata reale katsetele luua sünteetiline semiootikateooria, on lahknevused Peirce'i ja Saussure'i traditsioonide vahel osutunud ületamatuteks. Nende erinevuse aluseks on põhimõtteliselt erinev märgi loomuse kontseptsioon. Peirce'i jaoks on märk objekt, mis, asendades teist objekti, saab märgi tähenduseks (seda märgikontseptsiooni võib nimetada substitutiivseks). Saussure'i jaoks tähendust väljaspool märki ei eksisteeri, tähistaja ja tähistatav ei või eksisteerida teineteiseta (seda märgikontseptsiooni võib nimetada bilateraalseks). Substitutiivne kontseptsioon on atomistlik, sest ta põhimõisteks on (üksik) empiiriliselt antud märk, mis asendab (üksikut) objekti. Bilateraalne kontseptsioon eeldab holismi, sest ta alusmõisteks on abstraktne märkide süsteem, mida saab jaotada üksikmärkideks. Atomistlikus ja holistlikus semiootikas tuleb põhimõtteliselt erinevalt vaadelda ka semioosi. Atomistlikus semiootikas on semioosi aluseks identifikatsiooniprotsess, holistlikus semiootikas aga tõlkeprotsess. 